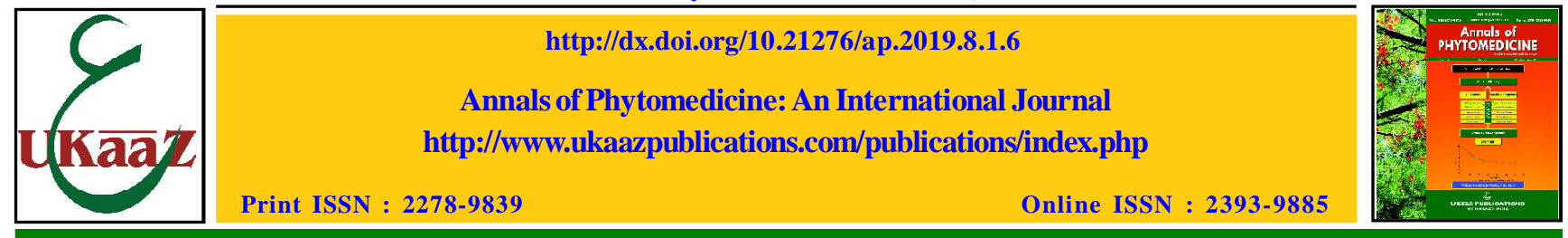

Original article

\title{
Effect of cultural condition on seed growth and content of essential oil of two populations and one cultivar of genus Nigella
}

\author{
Mahmut Camlica and Gulsum Yaldiz \\ Department of Field Crops, Faculty of Agriculture and Natural Sciences, Bolu Abant Izzet Baysal University, \\ Bolu-14280, Turkey
}

Received March 5, 2019: Revised April 25, 2019: Accepted April 27, 2019: Published online June 30, 2019

\begin{abstract}
Nigella is an important genus of family Ranunculaceae, used in traditional medicine for centuries to cure diseases like cancer, cardiovascular complications, diabetes, asthma, kidney disease, etc. The aim of this study is to evaluate the growth and esssential oil content of one cultivar of Nigella sativa L. (Cameli) and two cultivars of Nigella damascena L. (Ankara and Rize) populations under controlled conditions of Bolu. On average days to 50\% seedling and flowering determined as 15.67-18.0 days in 2017, 14.33-16.0 days in 2018, 69.0-75.33 days in 2017, 65.67-75.33 days in 2018, respectively. Seed weights per plant were 17.11-27.08 g in 2017 and 11.51-12.43 g in 2018; the 1000 seeds weights were between 2.18-2.84 g in 2017 and 2.37-2.77 g in 2018. Seed yield in the first year (38.02-60.18 kg da $\left.\mathrm{kg}^{-1}\right)$ was higher than the yield in the second year $\left(31.88-37.20 \mathrm{~kg} \mathrm{da}^{-1}\right)$. The essential oil content of the populations and cultivar was found to be very close to each other with $0.10-0.31 \%$, and essential oil compositions were between $5.68-51.06 \%$. The fatty oil rate in populations and cultivar varied between $20 \%$ and $29 \%$, and fatty acid compositions were between $66.83-91.58 \%$. The major inorganic matters were found as $\mathrm{K}^{+}$ (177.50-310.5 $\left.\mathrm{mg} \mathrm{g}^{-1}\right)$ and $\mathrm{Ca}^{+2}\left(58.90-128.0 \mathrm{mg} \mathrm{g}^{-1}\right)$ and followed by $\mathrm{Mg}^{+2}$ and $\mathrm{Na}^{+}$. The plant height, the number of branches, the number of capsule and 1000-seed weight of populations varied according to years. Generally, as compared to populations and cultivar, the best results were obtained in $N$. sativa cultivar.
\end{abstract}

Keywords: Essential oil, growth, Nigella sp., quality, yield

\section{Introduction}

The seeds of Nigella sativa L. (black cumin or black seed) have been used for thousands of years as a spice and food preservative. It is an annual herbaceous plant which is cultivated for its seeds and known as an edible plant, belongs to the Ranunculaceae family (Yaldiz and Camlica, 2018).

It is indigenous to Southern Europe, North Africa and Southeast Asia and extensively cultivated in many countries as Middle Eastern, Mediterranean Region, South Europe, India, Pakistan, Syria, Turkey and Saudi Arabia in the world (Karna, 2013).

Traditionally, black cumin is used as a medicament in a variety of disorders in the respiratory system, digestive tract, cardiovascular system, kidney, liver, and immune system as a medicament. It is also used as antiseptic and local anesthetic (Karna, 2013). Black cumin has been studied for biological activities and therapeutic potential and found to have wide spectrum of activities as diuretic, antihypertensive, antidiabetic, anticancer and immunomodulatory,

\footnotetext{
Author for correspondence: Mr. Mahmut Camlica

Research Assistant, Department of Field Crops, Faculty of Agriculture and Natural Sciences, Bolu Abant Izzet Baysal University, Bolu-14280, Turkey

E-mail: mcamlica25@outlook.com

Tel.: +90-5315265942
}

Copyright (ㅇ 2019 Ukaaz Publications. All rights reserved.

Email: ukaaz@yahoo.com; Website: www.ukaazpublications.com antimicrobial and anti-inflammatory, spasmolytic, bronchodilator, gastroprotective, hepatoprotective, renal protective and antioxidant properties (Khaled, 2009; Abel-Salam, 2012).

The seeds of black cumin contain important components as protein (26.7\%), fat $(28.5 \%)$, carbohydrates $(24.9 \%)$, crude fiber $(8.4 \%)$, total ash $(4.8 \%)$, essential oil $(0.5-1.6 \%)$, fatty oil (35.6-41.5\%) (Karna, 2013), cellulose (6.8-7.4\%) and moisture (8.1-11.6\%) (Heshmati and Namazi, 2015). They are also rich in various vitamins as A, B1, B2, B3 and C and minerals such as $\mathrm{Ca}, \mathrm{K}, \mathrm{Se}, \mathrm{Cu}$, P, Zn, Fe (Islam et al., 2017).

The aim of this study is to determin the important agricultural and quality characters of one cultivar of $N$. sativa (Cameli) and two $N$. damascena (Ankara and Rize) populations in controlled ecological conditions of Bolu.

\section{Material and Methods}

The study was carried out during growing seasons in 2017 and 2018 at Bolu Abant Izzet Baysal University, Bolu. The field experimental site was located at research and application area of Agriculture and Natural Sciences Faculty, is between $40^{\circ} 44^{\prime} 45^{\prime \prime} \mathrm{N}$ latitude, $31^{\circ} 37^{\prime} 46^{\prime \prime} \mathrm{E}$ longitudes with altitude of $881 \mathrm{~m}$. Seeds of black cumin were obtained from Ankara, Rize (populations) and Transitional Zone Agricultural Research Institute-Eskipehir (TZARI) (Cameli cultivar) (Table 1). 
Table 1: Information about black cumin populations and cultivar used in the study

\begin{tabular}{|l|c|}
\hline Black cumin cultivar/populations & Obtained from \\
\hline Ankara population & Ankara \\
Rize population & Rize \\
Cameli cultivar & TZARI \\
\hline
\end{tabular}

These seeds were sown (29 $9^{\text {th }}$ April 2017 and 2018) in a randomized complete block design (RCBD), having 3 replications with a distance of $0.3 \mathrm{~m}$ between rows and $0.2 \mathrm{~m}$ between plants. Average climatic data were recorded as $16.08^{\circ} \mathrm{C}, 17.10^{\circ} \mathrm{C}$; temperature; $41.37 \mathrm{~kg} . \mathrm{m}^{-2}$; $71.18 \mathrm{~kg} . \mathrm{m}^{-2}$ rainfall; $69.2 \mathrm{~kg} . \mathrm{m}^{-2}, 53.68 \mathrm{~kg} . \mathrm{m}^{-2}$ humidity during the vegetation periods for 2017 and 2018, respectively (Anonymous, 2019). Experimental area soils are clay-loam with a pH value of 7.5, organic matter content of $1.6 \%$, phosphorus ratio of $23.74 \mathrm{~kg} \mathrm{da}^{-1}$ and potassium ratio of $38 \mathrm{~kg} \mathrm{da}^{-1}$ (Anonymous, 2019).

In the experiment, $4 \mathrm{~kg} \mathrm{da}^{-1}$ diammonium phosphate (DAP) as base fertilizer and $8 \mathrm{~kg} \mathrm{da}^{-1}$ ammonium sulfate (AN) as top fertilizer were applied. These populations and cultivar were harvested between 29 August to 2 September, 2017, and 25-28 August, 2018.

Ten competitive plants from each parcel were randomly selected and morphological and some yield properties were taken for recording of data pertaining to black seed from these plants.

Essential oil analyses were carried out in accordance with method TS 8882. Approximately, $20 \mathrm{~g}$ sample was taken from the seeds of cultivar and populations and placed into glass clevenger flasks. 200 $\mathrm{ml}$ distilled water was added and samples were subjected to hydrodistillation for $3 \mathrm{~h}$. The amount obtained was recorded (in $\mathrm{ml}$ ) from the graduated section of the flask and then used to calculate percentage essential oil yields.

The essential oil composition of samples was analyzed using a gas chromatography (model 7890A, USA), coupled with a flame ionization detector and mass spectrometry (model 5975C) with a capillary column (HP-innowax capillary; $60.0 \mathrm{~m} \times 0.25 \mathrm{~mm} \times 0.25$ $\mu \mathrm{m})$. Essential oils were diluted (1:50) with hexane. GC MS/FID analysis was carried out, using a split mode of 50:1. Injection volume and temperature were adjusted to $1 \mu \mathrm{l}$ and $250^{\circ} \mathrm{C}$, respectively. Helium (99.9\%) was the carrier gas at a constant flow rate of $1 \mathrm{ml}$ $\min ^{-1}$. The oven temperature programme comprised: $60^{\circ} \mathrm{C}$ for 10 min, increasing at $20^{\circ} \mathrm{C} / \mathrm{min}$ to $250^{\circ} \mathrm{C}$, and then holding at $250^{\circ} \mathrm{C}$ for $8 \mathrm{~min}$. MS spectra were monitored between 35 and $450 \mathrm{amu}$ and the ionization mode used was electronic impact at $70 \mathrm{eV}$. The relative percentage of the components was calculated from GC-FID peak areas and components were identified using the WILEY, NIST and FLAVOR libraries (SITARC, 2019).

$5 \mathrm{~g}$ samples from each black cumin populations and cultivar were extracted with $\mathrm{n}$-hexan for $6 \mathrm{~h}$, using Soxhlet apparatus for determining the seed oil content $(\%)$.

The data were analyzed using XLSTAT statistical software program and obtained results were subjected to analysis of variance and least significant difference test (LSD) in order to find differences among the black cumin populations and cultivar at $p=0.05$.

\section{Results}

\section{$3.150 \%$ seedling period (days)}

There was not a significant differences among the black cumin populations and cultivar as statistically both in 2017 and 2018 years (Table 2). The 50\% seedling periods of black cumin changed between 14.33-18.00 days between two years. The earliest seedling period was determined in Cameli cultivar (14.33-15.67 days). The latest seedling period was found in Ankara population with 18.0 and 16.0 days in both the years

\subsection{Days to flowering time (days)}

Days to flowering time (50\%) ranged from 65.67 (Cameli) to 75.33 days (Cameli and Rize population) (Table 2). While the earliest days to flowering time was seen in Rize population (69.0 days) and Cameli (65.67 days), the latest days-to-flowering time was seen in Cameli (75.33 days) and Rize population (75.33 days) in 2017 and 2018, respectively. Flowering time of Ankara population was found similar in both the years (71.0-72.67 days).

\subsection{Plant height $(\mathrm{cm})$}

The variation with respect to plant height at harvest time ranged from 33.84-44.17 cm (Table 2). The highest plant height was recorded in Cameli cultivar, and follwed by Rize population (35.57 $\mathrm{cm})$ while Rize population had the lowest plant height $(39.50 \mathrm{~cm})$ in first year, Ankara population $(33.84 \mathrm{~cm})$ had in second year. Cameli cultivar was found higher than Ankara population in both the years.

\subsection{Number of branches per plant}

The number of branches were seen between 1.97-6.93 number plant $^{-1}$ (Table 2). While the highest number of branches were obtained from Ankara (6.93 number) and Rize (3.03 number) in 2017 and 2018, respectively. The least number of branches were obtained from Cameli cultivar (5.90 and 1.97 number) in both the years. Ankara population was found lower than Rize population in terms of number of branches in 2018 .

\subsection{Number of capsule in per plant (capsule plant ${ }^{-1}$ )}

The number of capsule was seen between 2.93-14.67 number plant $^{-1}$ (Table 2). While the highest number of capsule was obtained from Cameli (14.67 number) and Rize population (3.67 number) in 2017 and 2018, respectively. The least number of capsule was obtained from Rize population (9.67 number) in first year and Cameli cultivar (2.93 number) in second year. Ankara population was found between the Cameli cultivar and Rize population in first and second year.

\subsection{Seed weights per plant $\left(\mathrm{g}_{\text {plant }}{ }^{-1}\right)$}

The variation in seed weights per plant ranged from 11.51-27.08 g among the populations and cultivar (Table 2). While the highest value was found from Cameli cultivar (27.08 g) in 2017, and it was found from Ankara population (12.43 g) in 2018. The lowest values were found in Rize population in both the years as 17.11 and 11.51 g. Seed weights per plant of 2017 year were found higher than 2018 including populations and cultivar. 


\subsection{Seed weight (g)}

The variation in 1000 -seed weight ranged from 2.18 to $2.84 \mathrm{~g}$ in 2017 and 2018 (Table 2). There was a significant differences among the populations and cultivar in terms of 1000-seed weight in 2017, but there was no difference in 2018. Cameli cultivar had the highest 1000 -seed weight per plant (2.84 and $2.77 \mathrm{~g})$, and the lowest 1000seed weight was found in Ankara population (2.18 and $2.37 \mathrm{~g}$ ) in first and second year, respectively. Rize population was found between Cameli and Ankara population in both the years with 2.32 and $2.44 \mathrm{~g}$.

\subsection{Seed yield $\left(\mathrm{kg} \mathrm{da}^{-1}\right)$}

Seed yield is the most important part of the plant because of including essential oil, fatty oil or using as spice or medicine.

The range for seed yield was 31.88-60.18 $\mathrm{kg} \mathrm{da}^{-1}$ in cultivation years (Table 2). Cameli cultivar $\left(60.18 \mathrm{~kg} \mathrm{da}^{-1}\right)$ gave the highest seed yield in first year, however, Ankara population had the highest seed yield in second year. The lowest seed yield was registered for Rize population $\left(38.02 \mathrm{~kg} \mathrm{da}^{-1}\right)$ and Cameli cultivar $\left(31.88 \mathrm{~kg} \mathrm{da}^{-1}\right)$ in 2017 and 2018 , respectively.

Table 2: Morphological and yield properties of black cumin populations and cultivar

\begin{tabular}{|c|c|c|c|c|c|c|c|c|c|c|c|c|c|c|c|c|}
\hline \multirow[t]{2}{*}{$\begin{array}{l}\text { Populations } \\
\text { /cultivar }\end{array}$} & \multicolumn{2}{|c|}{$\overline{S P(d a y s)}$} & \multicolumn{2}{|c|}{ FT (days) } & \multicolumn{2}{|c|}{ PH (cm) } & \multicolumn{2}{|c|}{$\begin{array}{c}\text { NB } \\
\text { (No/plant) }\end{array}$} & \multicolumn{2}{|c|}{$\begin{array}{c}\text { NC } \\
\text { (No/plant) }\end{array}$} & \multicolumn{2}{|c|}{ SW (g) } & \multicolumn{2}{|c|}{$1000 \mathrm{SW}$} & \multicolumn{2}{|c|}{ SY (kg/da) } \\
\hline & 2017 & 2018 & 2017 & 2018 & 2017 & 2018 & 2017 & 2018 & 2017 & 2018 & 2017 & 2018 & 2017 & 2018 & 2017 & 2018 \\
\hline Ankara & 18.0 & 16.0 & 71.0 & $72.67 \mathrm{AB}$ & 44.17 & 35.17 & 5.90 & 1.97 & 14.67 & 2.93 & 27.08 & $11.93 \mathrm{~B}$ & $2.84 \mathrm{~A}$ & 2.77 & 60.18 & 31.88 \\
\hline Rize & 16.67 & 15.33 & 69.0 & $75.33 \mathrm{~A}$ & 41.77 & 33.84 & 6.93 & 2.63 & 13.00 & 3.53 & 24.00 & $12.43 \mathrm{~A}$ & $2.32 \mathrm{~B}$ & 2.44 & 53.34 & 37.20 \\
\hline Çameli & 15.67 & 14.33 & 75.33 & $65.67 \mathrm{~B}$ & 39.50 & 35.57 & 6.80 & 3.03 & 9.67 & 3.67 & 17.11 & $11.51 \mathrm{C}$ & $2.18 \mathrm{~B}$ & 2.37 & 38.02 & 34.17 \\
\hline LSD (5\%) & 3.54 & 4.78 & 6.59 & 7.56 & 12.29 & 5.51 & 4.14 & 0.68 & 15.09 & 3.85 & 26.58 & 0.035 & 0.36 & 0.34 & 59.06 & 21.96 \\
\hline
\end{tabular}

SP: Seedling period; FT: Flowering time; PH: Plant Height; NC: Number of Capsule; SW: Seed Weight; 1000SW: 1000 Seed Weight; SY: Seed Yield. Different letters indicate significant differences at $(P<0.05)$ using LSD test

\subsection{Essential oil (\%)}

There was a significant differences among the populations and cultivar (Table 3). The essential oil ranged from 0.10 to $0.31 \%$ in populations and cultivar in 2017. Cameli cultivar gave the lowest value $(0.1 \%)$ and Ankara population had the highest value $(0.31 \%)$.

\subsection{Essential oil components (\%)}

Generally, 20 essential oil components were determined among the populations and cultivar (Figure 1). The major essential oil components were found p-cymen-2-ol (12.81\%) in Cameli cultivar, $\beta$-terpinolen (35.13\%) in Ankara population and farnesol (3.49\%) in Rize population (Figure 1).

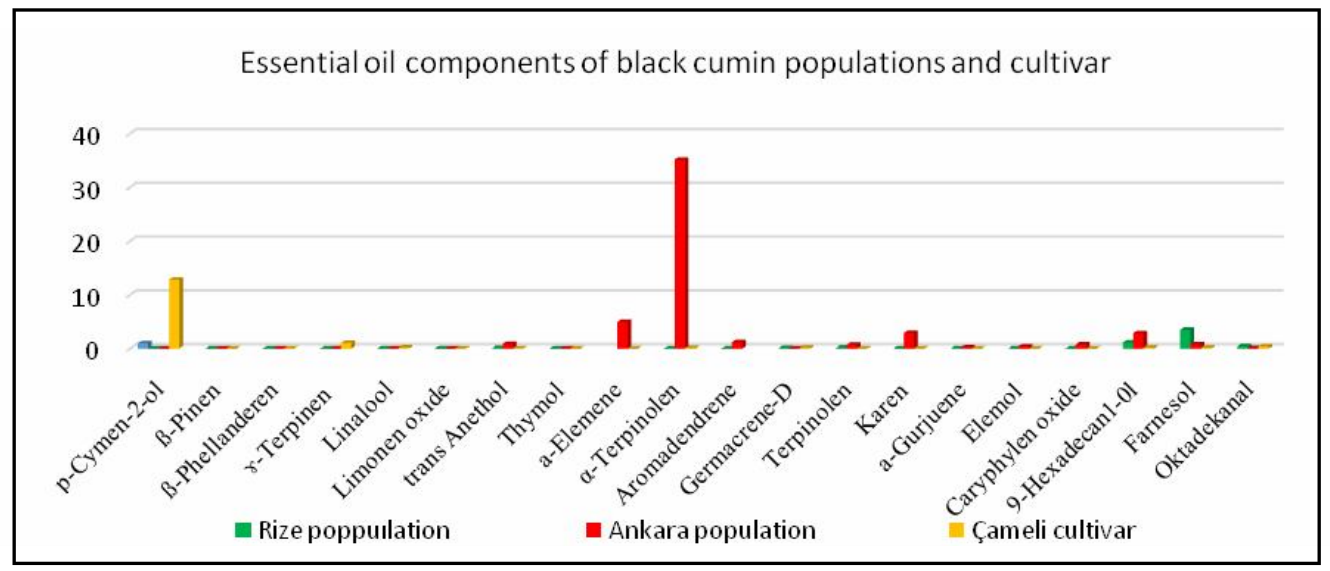

Figure 1: Essential oil components of black seed populations and cultivar.

\subsection{Seed oil (\%)}

There was no significant difference among the populations and cultivar (Table 3). The seed oil ranged from 20.0 to $29.33 \%$ in populations and cultivar in 2017. Cameli cultivar $(20.0 \%)$ gave the lowest value, Ankara population (25\%) had the highest value in terms of seed oil.

\subsection{Fatty acid compositions (\%)}

The fatty acid compositions (ratio of unsaturated to saturated fatty acids) in edible oils and fats are very significant for human nutrition.
Seed oil of black cumin is also used for edible purpose, because it is thought as one among newer sources of edible oils. It shows an important role in human nutrition and health (Tulukcu, 2011). 18 fatty acid compositions (10 saturated fatty acid, 8 unsaturated fatty acid) were found in black cumin populations and cultivar. The main fatty acid compositions were found as linoleic acid (38.48$41.69 \%)$ and oleic acid (13.26-17.08\%). Fatty oil components of black cumin populations and cultivar also contained palmitic acid (8.6-9.77\%), stearic (2.07-2.85\%), arachidic acid (2.67-8.26\%) and trace amount of other acids (Figure 2). 
Table 3: Essential oil and seed oil of black cumin populations and cultivar

\begin{tabular}{|l|c|c|}
\hline Populations /cultivar & $\begin{array}{c}\text { Essential oil (\%) } \\
\mathbf{2 0 1 7}\end{array}$ & $\begin{array}{c}\text { Seed oil (\%) } \\
\mathbf{2 0 1 7}\end{array}$ \\
\hline Ankara & $0.31 \mathrm{~A}$ & 25.00 \\
Rize & $0.25 \mathrm{~B}$ & 29.33 \\
Cameli & $0.10 \mathrm{C}$ & 20.00 \\
\hline LSD (5\%) & 0.06 & 28.32 \\
\hline
\end{tabular}

Different letters indicate significant differences at $(p<0.05)$ using LSD test

\subsection{Inorganic matter $\left(\mathrm{mg} \mathrm{g}^{-1}\right)$}

The inorganic matter of populations and cultivar was found between $177-310 \mathrm{mg} / \mathrm{g}$ for $\mathrm{K}^{+}, 58.90-128.0 \mathrm{mg} / \mathrm{g}$ for $\mathrm{Ca}^{+2}, 14.85-33.55 \mathrm{mg} / \mathrm{g}$ for $\mathrm{Mg}^{+2}$ and 16.14-26.10 mg/g for $\mathrm{Na}^{+}$(Figure 3).

$\mathrm{K}^{+}$was found the highest in Cameli cultivar $(310 \mathrm{mg} / \mathrm{g})$ and $\mathrm{Ca}^{+2}$, $\mathrm{Mg}^{+2}$ and $\mathrm{Na}^{+}$were (determined) the highest values in Rize population with $128,33.55$, and $26.10 \mathrm{mg} / \mathrm{g}$, respectively. It was noted that the inorganic matters of black cumin were found for $\mathrm{K}^{+}(61.2-67.5 \mathrm{mg} / \mathrm{g}), \mathrm{P}(37.0-43.1 \mathrm{mg} / \mathrm{g}), \mathrm{Na}^{+2}(35.0-46.2 \mathrm{mg} /$ g), $\mathrm{Fe}(1.0-1.5 \mathrm{mg} / \mathrm{g}), \mathrm{Ca}^{+2}(27.8-30.7 \mathrm{mg} / \mathrm{g})$ and $\mathrm{Mg}^{+}(13.4-14.7$ mg/g) (Ashraf et al.,2006). Yaldiz and Camlica (2018) reported that inorganic matter of black cumin changed for $\mathrm{K}^{+}$(48.3-89.9 $\mathrm{mg} / \mathrm{g}), \mathrm{Ca}^{+2}(33.6-67.8 \mathrm{mg} / \mathrm{g}), \mathrm{Cl}^{-}(6.5-18.1 \mathrm{mg} / \mathrm{g}), \mathrm{Na}^{+}(9.3-22.57$ $\mathrm{mg} / \mathrm{g}), \mathrm{Mg}^{+2}(11.0-21.2 \mathrm{mg} / \mathrm{g}), \mathrm{SO}_{4}^{-2}(13.9-18.1 \mathrm{mg} / \mathrm{g})$ in leaves and roots in black cumin.

\subsection{Dendrogram and biplot analysis}

The dendrogram analysis separated as $N$. sativa and $N$. damascena. It divided two main groups (Group A and B). Group A consisted only the black cumin cultivar and Group B included black cumin populations (Ankara and Rize populations). N. sativa was different from $N$. damascena, based on examined properties.

10 measured quantitative and qualitative morphological traits were observed and analyzed are presented in Figure 5. The first principal component (PC1) accounted for $84.7 \%$ of the total variance in terms of SY, SW and essential oil. The second principal component (PC2) had high contributing factor, loadings from the analyzed traits seed per pod and pod length, and contributed $15.3 \%$ to the total variation. SY and SW were determined in the same region and seed oil was took place in another region and others were seen together in the same region. The black cumin cultivar and populations were seen in different regions in biplot analysis.

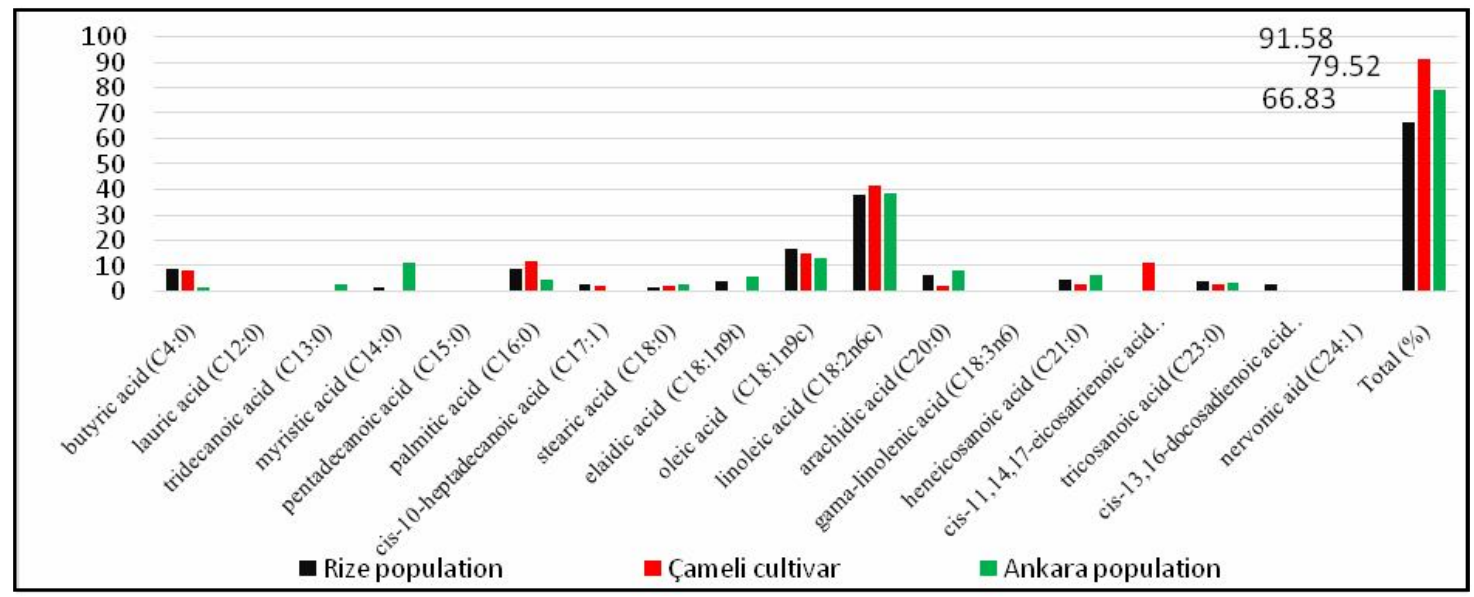

Figure 2: Fatty acid components of black seed populations and cultivar.

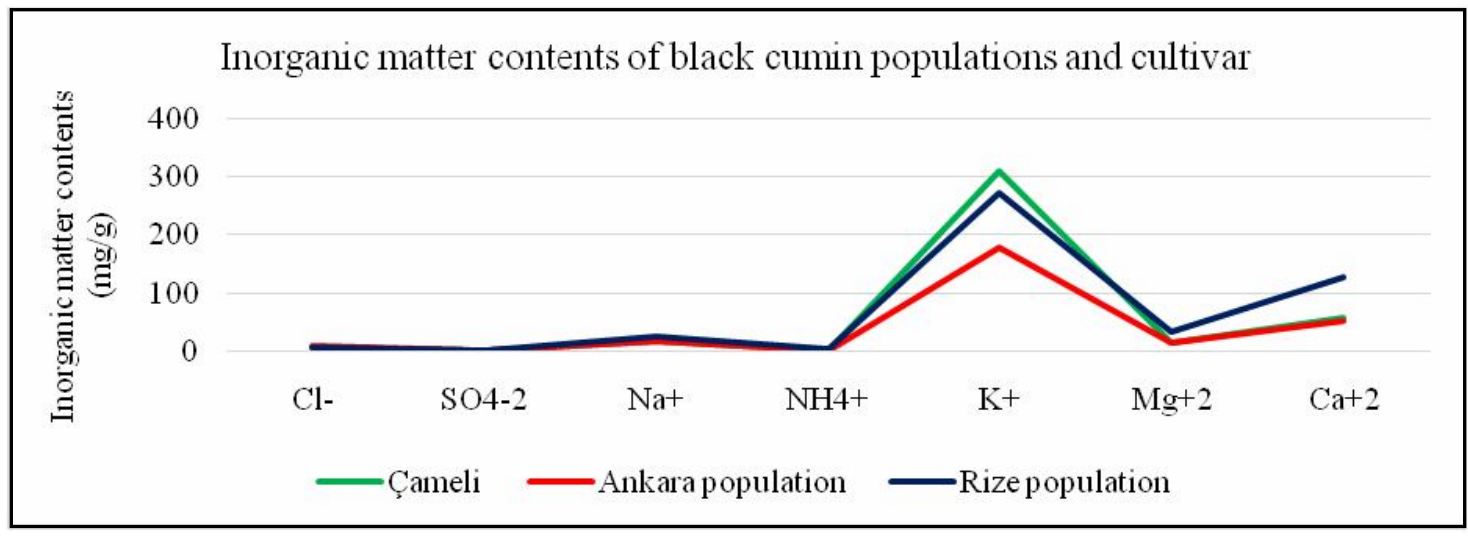

Figure 3: Inorganic matter of black seed populations and cultivar. 


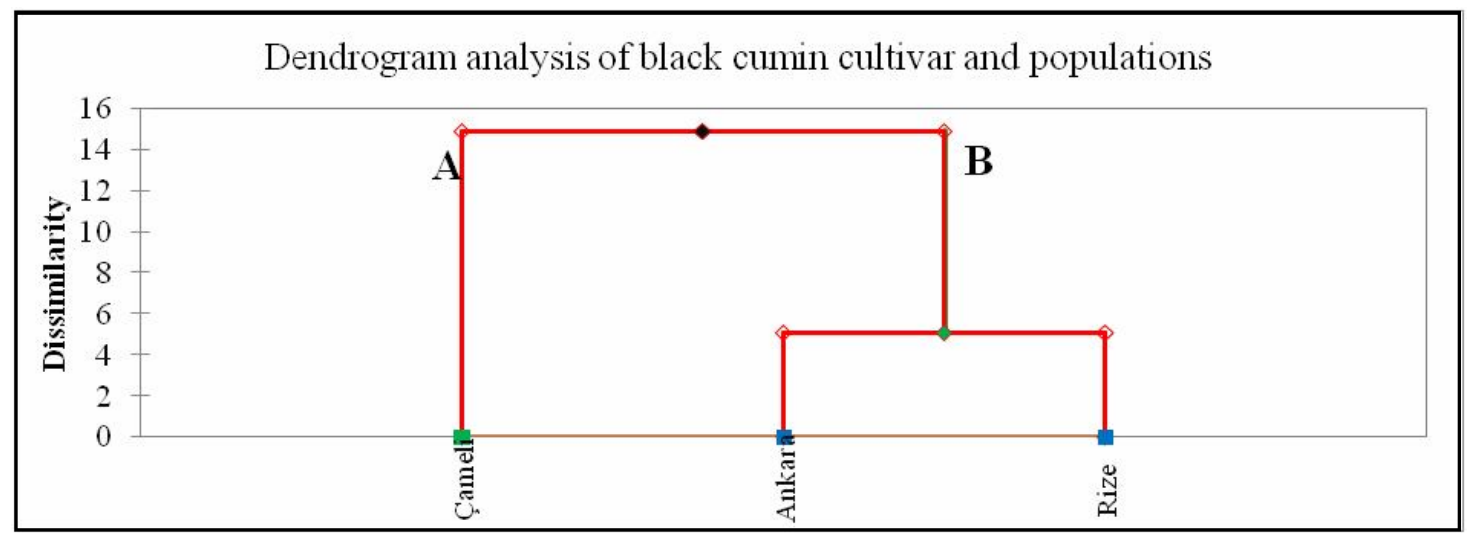

Figure 4: Dendrogram analysis of the black cumin cultivar and populations based on examined properties.

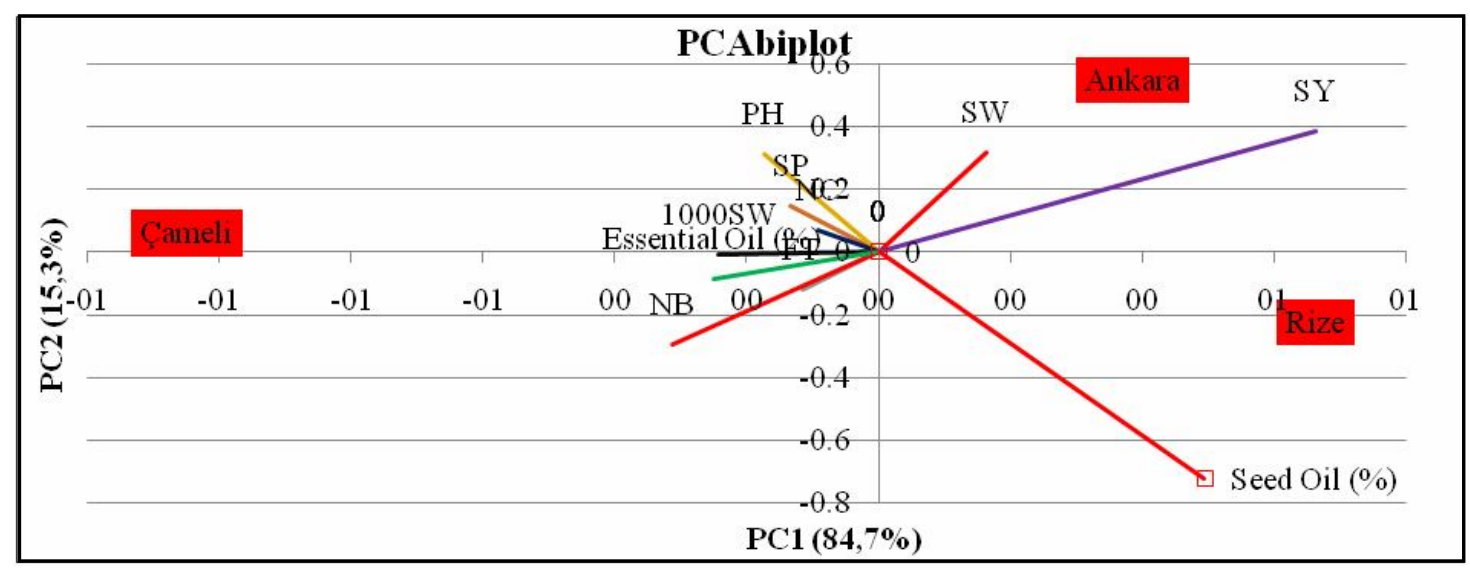

Figure 5: Distribution of the 3 analyzed black cumin in the first two principal components based on the main sources of variance.

\section{Discussion}

It was noted that plant height was changed between $16.1-47.1 \mathrm{~cm}$ (Kara et al., 2018), 29.67-38.53 cm (Ghamarnia et al., 2010). Similarly, Tektas (2015) reported that plant height was determined as 63.87-70.37 cm, Kilic and Arabaci (2016) as 39.33-78.90 cm and Sahin (2013) 17.2-53.1 cm, Senyigit and Arslan (2018) as 23.3$68.1 \mathrm{~cm}$ in black cumin. Our results were found partly similar with other reserachers except Tektas (2015). These differences could be due to probably variations in ecological conditions, agronomic applications, genotypes and soil properties.

Kara et al. (2018) reported 2.0-5.3 number range for number of branches in 5 black cumin populations in Isparta and Eskisehir ecological conditions. Branch number of black cumin changed between 3.7-7.6 number in Afyonkarahisar condition (Senyigit and Arslan, 2018). The results were found similar as reported by other researchers.

It was noted that number of capsule per plant of black cumin varied between 2.1-7.7 number by Kara et al. (2015). The number of capsule varied between 3.17-5.60 (Özel et al.,2002), 4.5-4.9 (Taqi, 2013), 4.03-7.63 (Kosar and Ozel, 2015) and 5.9-17.9 (Senyigit and Arslan, 2018). Our results were found partly similar with these researchers.

Kosar and Ozel (2018) reported that 1000-seed weight ranged from 1.67 to $3.40 \mathrm{~g}$ in 33 different black cumin variety and populations. It was also noted that 1000 -seed weight changed between 1.21 -
$2.62 \mathrm{~g}$ (Akgören, 2011), 2.22-2.69 g (Kulan et al., 2012), 2.57-2.78 (Taqi, 2013), 2.45-2.67 g (Kara et al.,2015), 2.40-2.90 g (Tektas, 2015). The obtained values were found partly similar with other researchers. The differences can be explained due to different black cumin genotypes, environmental and growing conditions. In addition, the difference between the years can be because of the environmental conditions as temperature, amount of precipitation in the seed development periods of plants (Table 2).

Kara et al. (2018) reported seed weight range between 19.77-94 kg $\mathrm{da}^{-1}$. Similarly, Ghamarnia and Jalili (2013) reported 2.13-113.1 kg $\mathrm{da}^{-1}$ range for seed yield. The seed yield obtained in the present study was lower than top findings of other researchers in the literature. The observed differences may be due to different environmental and genetic factors, different chemotypes and the nutritional status of the plants. In addition to this, Kara et al. (2018) reported that essential oil ranged from $0.10 \%$ to $0.78 \%$ in Isparta and Eskisehir ecological conditions. The essential oil was found between $0.48-0.55 \%$ (Tunçtürk et al., 2005), 0.08-0.20 (Tektas, 2015). The obtained values were found partly similar with other researchers.

Generally, the highest essential oil component was found in Ankara population with $51.06 \%$ and the lowest was found in Rize population with $5.68 \%$. The essential oil component was found as $98.7 \%$ and it was also noted that the main essential oil components were determined as p-cymene $(60.2 \%)$ by Wajs et al. (2008). P-cymene was found between $0.33-38.0 \%$ as main component in different 
techniques as reported by Benkaci-Ali et al. (2013). The results obtained in the present study are different to those reported in previous studies. It was thought that environmental conditions, genetic differences and growth conditions may be the cause of differences.

Kara et al. (2018) reported that seed oil varied between 20.6-33.6\%. Similarly, seed oil changed between $29.10-30.40 \%$ (Ghamarnia et al. 2010), 27.93-41.20\% (Tektas, 2015), 31.73-38.40\% (Kilic and Arabaci, 2016), 36.42-40.17\% (Kosar and Özel, 2018). The results were found partly similar with other researchers, except Kilic and Arabaci (2016) and Kosar and Özel (2018). It can be considered that the differences in results are based on genotypes, ecological and grown conditions.

The highest fatty acid component was found in Cameli cultivar with $91.58 \%$ and the lowest was found in Rize population with $66.83 \%$. The linoleic and oleic acids were found as $53.14-56.82 \%$, $23.02-24.42 \%$ by Parhizkar et al. (2011), respectively. The linoleic acid was noted as $61.25 \%$ and oleic acid was reported as $17.63 \%$ by Thilakarathna et al. (2018). Linoleic and oleic acids were found as major components in different nitrogen applications with 53.72$54.66 \%$ and $23.87-25.69 \%$, respectively (Ashraf et al., 2006). The main fatty acid of our study was found lower than reported by other researchers in terms of linoleic and oleic acid. This result can be explained because of different genotypes, ecological and growning conditions.

The obtained results were found partly similar with Ashraf et al. (2006) in terms of $\mathrm{Ca}^{+2}$ and found similar with Yaldiz and Camlica (2018) in terms of $\mathrm{Ca}^{+2}, \mathrm{Mg}^{+2}$. Other inorganic matters were found lower than other researchers. This situation can be explained due to genotypes, other growing and ecological conditions.

\section{Conclusion}

The plant height, number of branches and number of capsules, and 1000 -seed weight of selected populations varied according to years. Generally, as compared to populations and cultivar, the best results were obtained in $N$. sativa cultivar in terms of morphological properties. For quality characterizations, Ankara population showed the highest values as compared the Rize population and Cameli cultivar except inorganic matter.

\section{Conflict of interest}

The authors declare that no conflict of interest exists in the course of conducting this research. Both the authors had final decision regarding the manuscript and the decision to submit the findings for publication.

\section{Acknowledgments}

This work was supported by the Scientific Research Unit of Bolu Abant Izzet Baysal University (ÖBAP-2018.10.07.1281).

\section{References}

Abel-Salam, B. K. (2012). Immunomodulatory effects of black seeds and garlic on alloxan-induced diabetes in albino rat. Allergol. Immunopathol. (Madr), 40(6):336-340.

Akgören, G. (2011). Bazý Çörek Otu (Nigella sativa L.) Populasyonlarýnýn Tarýmsal Özellikleri. Eskipehir Osmangazi Üniversitesi, Fen Bilimleri Enstitüsü, Basýlmamýp Yüksek Lisans Tezi, Eskipehir.

Anonymous (2019). Bolu Meteorology General Directorate. Bolu, Turkey: Turkish State Meteorological Service.
AOAC (1990). Fatty acids in oil and fats. In: Official methods of analysis, 15 th ed. AOAC, Arlington, USA: Ed. Helrich K, 2:963964.

Ashraf, M.; Ali, Q. and Iqbal, Z. (2006). Effect of nitrogen application rate on the content and composition of oil, essentialoil and minerals in black cumin (Nigella sativa L.) seeds. Journal of the Science of Food and Agriculture, 86:871-876.

Benkaci-Ali, F.; Akloul, R.; Boukenouche, A. and De Pauw, E. (2013). Chemical composition of the essential oil of Nigella sativa seeds extracted by microwave steam distillation. Journal of Essential Oil-bearing Plants, 16(6):781-794.

Ghamarnia, H. and Jalili, Z. (2013). Water stress effects on different black cumin (Nigella sativa L.) components in a semi-arid region. International Journal of Agronomy and Plant Production, 4(4): 753-762.

Ghamarnia, H.; Khosravy, H. and Sepehri, S. (2010). Yield and water use efficiency of (Nigella sativa L.) under different irrigation treatments in a semi-arid region in the west of Iran. Journal of Medicinal Plants Research, 4(16):1612-1616.

Heshmati, J. and Namazi, N. (2015). Effects of black seed (Nigella sativa L.) on metabolic parameters in diabetes mellitus: A systematic review. Complementary Therapies in Medicine, 23(2):275-282.

Islam, M. T.; Guha, B.; Hosen, S.; Riaz, T. A. and Shahadat, S. (2017). Nigellalogy: A review on Nigella sativa. MOJ Bioequivalence and Bioavailability, 3(6): $167-181$.

Kara, N.; Katar, D. and Baydar, H. (2018). Yield and quality of black cumin (Nigella sativa L.) populations: The effect of ecological conditions. Turkish Journal of Field Crops, 20(1):9-14.

Karna, S. K. L. (2013). Phytochemical screening and gas chromatography - mass spectrometry and analysis of seed extract of Nigella sativa Linn. International Journal of Chemical Studies, 1(4):183-188.

Khaled, A. A. S. (2009). Gastroprotective effects of Nigella sativa oil on the formation of stress gastritis in hypothyroidal rats. International Journal of Physiology, Pathophysiology and Pharmacology, 1:143-149.

Kulan, E.G.; Turan, Y.S.; Gulmezoglu, N.; Kara, 0. and Aytac, Z. (2012). Kuru Koullarda Yetitirilen Corekotunun (Nigella sativa L.) Baz1 Agronomik ve Kalite Ozellikleri. Tibbi ve Aromatik Bitkiler Sempozyumu, 177-181, Tokat.

Kilic, C. and Arabaci, O.(2016). The effect of different sowing times and seed rate on the yield and quality of black cumin (Nigella sativa L.). Journal of Adnan Menderes University Agricultural Faculty, 13(2):49-56.

Kosar, Y. and Ozel, A. (2018). Characterization on variety and populations of black cumin (Nigella sativa L.): I. Agricultural properties. Harran Journal of Agricultural and Food Science, 22(4):533-543.

Ozel, A.; Demirbilek, T. and Güler, Y. (2002). Effect of different sowing dates on yield and some agronomic characters of black cumin species under Harran plain arid conditions. Harran Journal of Agricultural and Food Science, 6(3-4):81-84.

Parkizar, S.; Latiff, L. A. and Abd Rahman, S. (2011). Comparison of the supercritical fluid extraction with conventional extraction methods to determine the fatty acid composition of black cumin seeds. Scientific Research and Essays, 6(34):6817-6820.

SITARC (2019). Scientific Industrial and Technological Application and Research Center. Available: https://betum.ibu.edu.tr/ kromatografi.Bolu [28 April 2019]. 
Sahin, B. (2013). Farklý ekim zamanlarýnda yetiptirilen bazý týbbi bitkilerin verim ve kalite özelliklerinin belirlenmesi. Selçuk Üniversitesi Fen Bilimleri Enstitüsü, Tarla Bitkileri Anabilim Dalý, Yüksek Lisans Tezi, Konya.

Senyigit, U. and Arslan, M.(2018). Effects of irrigation programs formed by different approaches on the yield and water consumption of black cumin (Nigella sativa L.) under transition zone in the West Anatolia conditions. Journal of Agricultural Sciences, 24:22-32.

Taqi, H. (2013). Samsun Kopullarýnda Bazý Çörekotu (Nigela sativa L.) Popülasyonlarýnda Önemli Tarýmsal ve Kalite Özelliklerinin Belirlenmesi. Ondokuz Mayýs Üniversitesi, Fen Bilimleri Enstitüsü, Tarla Bitkileri Anabilim Dalý, (Basýlmamýp Yüksek Lisans Tezi), Samsun.

Tektas, E. (2015). Harran Ovasý Kopullarýnda Birim Alandaki Tohum Sayýsýnýn Çörek Otu (Nigella sativa L.)'nun Verim ve Bazý Bitkisel Özelliklerine Etkisi, (Basýlmamýp Yüksek Lisans Tezi) Harran Üniversitesi Fen Bilimleri Enstitüsü, Panlýurfa.
Thilakarathna, R. C. N.;Madhusankha, G. D. M. P. and Navaratne, S. B. (2018). Determination of composition of fatty acid profile of Ethiopian and Indian black cumin oil (Nigella sativa). International Journal of Food Science and Nutrition, 3(3):01-03.

Tulukçu, E. (2011). A comparative study on fatty acid composition of black cumin obtained from different regions of Turkey, Iran and Syria. African Journal of Agricultural Research, 6(4):892-895.

Tunçtürk, M.; Ekin, Z. and Türközü, D.(2005). Response of black cumin (Nigella sativa L.) to different seed rates growth, yield components and essential oil content. Journal of Agronomy, 4(3):216-219.

Wang, M.; Fu, Y. and Liu, H.(2016). Nutritional quality and ions uptake to PTNDS in soybeans. Food Chemistry, 192:750-759.

Wajs, A.; Bonikowski, R. and Kalemba, D. (2008). Composition of essential oil from seeds of Nigella sativa L. cultivated in Poland. Flavour and Fragrance Journal, 23:126-132.

Yaldiz, G. and Camlica, M. (2018). The effects of different potassium doses on some element content of black seed (Nigella sativa L.). Bahçe, 47(2):295-298.

Citation: Mahmut Camlica and Gulsum Yaldiz (2019). Effect of cultural condition on seed growth and content of essential oil of two populations and one cultivar of genus Nigella. Ann. Phytomed., 8(1):56-62. 